\title{
Opportunistic Intestinal Protozoan Infections and Immunological Status of HIVIAIDS Patients in Jalingo Local Government, Taraba State
}

\author{
Elkanah Obadiah Sambo ${ }^{1}$, Onyeuku Okechukwu Chinwe ${ }^{2,}$, Obiorah Sylvester Chibuozor ${ }^{3}$, \\ Elkanah Deborah Sambo', Egeonu Stephen Ugoeze ${ }^{3}$ \\ ${ }^{1}$ Department of Biological Sciences, Taraba State University, Jalingo, Nigeria \\ ${ }^{2}$ Department of Laboratory Services, Taraba State Specialist Hospital, Jalingo, Nigeria \\ ${ }^{3}$ Department of Laboratory Services, Federal Medical Centre, Jalingo, Nigeria
}

Email address:

okechukwuonyeuku66@gmail.com (O. O. Chinwe)

${ }^{*}$ Corresponding author

\section{To cite this article:}

Elkanah Obadiah Sambo, Onyeuku Okechukwu Chinwe, Obiorah Sylvester Chibuozor, Elkanah Deborah Sambo, Egeonu Stephen Ugoeze. Opportunistic Intestinal Protozoan Infections and Immunological Status of HIV/AIDS Patients in Jalingo Local Government, Taraba State. American Journal of Laboratory Medicine. Vol. 5, No. 5, 2020, pp. 139-143. doi: 10.11648/j.ajlm.20200505.12

Received: July 18, 2020; Accepted: August 19, 2020; Published: September 21, 2020

\begin{abstract}
The Human Immunodeficiency Virus (HIV) is a virus that attacks the immune system. Opportunistic intestinal protozoans are among the major contributors to the global intestinal parasite load. This study investigated the danger and complication due to intestinal protozoans' infection among HIV/AIDS patients in Jalingo metropolis. The study also compared the prevalence of opportunistic intestinal protozoa infection and $\mathrm{CD}^{4+}$ T-Cell count between HIV/AIDS and non HIV patients. The procedure of wet mount technique and faecal concentration methods were employed. The $\mathrm{CD}^{4+}$ count of patients were determined using the Partee Cyflow Counter, which determines the percentage of $\mathrm{CD}^{4+}$ cells of individuals. The prevalence of opportunic intestinal protozoan parasites was higher among female positives, $68(19.60 \%)$ than the male, $50(16.50 \%)$ with no significant difference $(\mathrm{p}>0.05)$. The infection based on age groups revealed that the age group 10-15 years had the highest prevalence of 27 (48.21\%) while the age group 41-45 years had the least prevalence of $2(2.63 \%)$. The prevalence of intestinal parasites was highly significant among the study participants with $\mathrm{CD}^{4+}$ count $<200$ cells/ $\mu$. Cryptosporidium spp was significantly associated with HIV positive subjects who had $\mathrm{CD}^{4+}$ count of less than $200 \mathrm{cell} / \mu \mathrm{l}$. The prevalence of intestinal parasites was highly significant among the study participants with $\mathrm{CD}^{4+}$ count $<200$ cells/ul. The implications of these findings are discussed and solution proposed to curb opportunistic infections among HIV/AIDS patients.
\end{abstract}

Keywords: Immunological, Opportunistic, Protozoans, HIV/AIDS, Taraba

\section{Introduction}

The Human Immunodeficiency Virus (HIV) is a virus that attacks the immune system which is the body's natural defense against illnesses. A person infected with HIV finds it more difficult to fight infection diseases. The viruses destroy white cell called T-helper cells, replicating inside them. T-helper cells are also known as CDs cells. There are two types of HIV: type- 1 is the most common type and it is found worldwide. HIV-2 is found mostly in West Africa and in some cases in India and Europe [1].
The status of HIV/AIDS scourge in sub-sahara Africa. According to UNAIDS report on global HIV/AIDS, sub-Sahara Africa is the world's epicenter of HIV/AIDS despite the fact that this region contains only about $11 \%$ of the earth's population. Prevalence of HIV in adult is $1.2 \%$ worldwide. (0.6\% in North America but 9.0\%) in sub-Sahara Africa). Five million adults and children became infected with HIV in 2001, 3.5 million people from sub-sahara Africa alone [2]. Of all people living with HIV/AIDS global, 9\% of them live in Nigeria [2], as of 2014 in Nigeria, HIV among adults aged between 15-49 years was 3.17\% [2]. According to a recent report of News Agency of Nigeria, Rivers State has the 
highest prevalence $(15.2 \%)$ of HIV/AIDS in Nigeria. HIV infection causes a progressive destruction of the cell mediated (CMI) system by eliminating $\mathrm{CD}^{4+}$ or T-helper lymphocytes. Decreased immunity leads to opportunistic infections and certain cancers [1].

Opportunistic intestinal protozoans are among the major contributors to the global intestinal parasite load. In different parts of the world a wide variety of intestinal parasites like Ascaris lumbricoides, Entamoeba spp, Toxoplasma, Cyclospora, Giardia and Cryptosporidium.

HIV/AIDS is a scourge in sub-Sahara Africa despite the ameliorating effects of highly active antiretroviral Therapy (HAART). The prevalence of HIV/AIDS in Taraba State is $10.5 \%$ [2]. Opportunistic intestinal protozoan infections pose a great danger to the HIV/AIDS patients with complications. There is therefore the need to investigate the activities of instestinal protozoa parasites in AIDS related complexes in Jalingo Local Government. This study investigated the danger and complication due to intestinal protozoans' infection among HIV/AIDS patients in Jalingo metropolis. The study also compared the prevalence of opportunistic intestinal protozoa infection and $\mathrm{CD}^{4+}$, T-Cell count between HIV/AIDS and non HIV patients.

\section{Materials and Methods}

\subsection{Study Area}

Jalingo is the capital of Taraba State and the headquarters of Jalingo Local Government. The Local Government borders Ardo-Kola in the south, Lau Local Government in the North, Yorro Local Government to the East. Majority of the inhabitants of the L. G. A live in rural agricultural communities with civil service and farming as the major occupation. Jalingo Local Government is located between latitude $8^{\circ} 89^{\prime \prime} \mathrm{N}$, longitude $11^{\circ} 38^{\prime}$ E.

\subsection{Ethical Permission}

Ethical permission was sought and obtained from Postgraduate review committee of Department of Biological Sciences, Taraba State University, Jalingo. Futhermore, additional permission was sought and obtained from the various hospital management before the commencement of study.

\subsection{Research Design and Sample Collection}

The design of the study is hospital base, cross sectional study. A total of 650 stool samples were collected from both male and female HIV/AIDS patients and 200 stool samples were also collected from non-HIV/AIDS patients to serve as control. Permission of the parents, hospital and patients was sought for, before the commencement of the study. Each patient was provided with a pre-labelled $60 \mathrm{ml}$ universal sample bottle for stool collection. The patients were instructed on how to collect the sample. The samples were preserved and transported to the laboratory Department of Taraba State Specialist hospital Jalingo, for analysis.

\subsection{Questionnaires' Administration}

A questionnaire relevant to the study was issued to each patient to obtain information on: age, sex, level of education, occupation of parents, and history of previous health status. Qualitative data on environmental/predisposing factors such as type of toilet facility, source of drinking water were obtained from the participants.

\subsection{Microscopic Examination of the Stool}

Two methods to examine the stool were employed in this study: the wet mount and the concentration techniques as described [3].

For he wet mount technique, a microscope slide was obtained and one drop of normal saline was placed on one end of the slide. A drop of iodine was placed on the other end to incorporate into the faeces-saline mixture after an initial examination for motile trophozoites. A small amount of the stool was introduced to the drop or saline and another similar specimen into dilute iodine before mounted on the microscope to be examined under low-power magnification.

Faecal concentration was processed by the sedimentation method. Half tea spoonful of feaces was thoroughly mixed in $10 \mathrm{ml}$ of water and strained through two layer of gauze in a funnel. The filtrate was centrifuged at 2000rpm for 2 minutes, the supernatant was discarded and the sediment was re-suspended in $10 \mathrm{ml}$ of physiological saline, centrifuged again and the supernatant discarded. The sediment was re-suspended in $7 \mathrm{ml}$ of formalin saline and allowed to stand for 10 minutes for fixation. About $3 \mathrm{ml}$ of ether was then added. The tube was stoppered and shaken vigorously to mix, then the stopper was removed and the tube was centrifuged at $2000 \mathrm{rpm}$ for 2 minutes. The tube was allowed to rest in a stand and four layers became visible. The top layers consisted of ether, second a plug of debris, third a clear layer of formalin saline and the fourth was the sediment. Then the plug of debris was detached from the side of the tube with a glass rod and the liquid was poured off leaving a small amount of formalin saline for suspension of the sediment. It was poured on a clean glass slide covered with cover slip and examined under a microscope using $x 40$ objective. The sediment was also mixed with a drop of iodine and examined in the same manner.

\subsection{Method for $\mathrm{CD}^{4+}$ Count Analysis}

The $\mathrm{CD}^{4+}$ count of patients were determined using the Partee Cyflow Counter, which determines the percentage of $\mathrm{CD}^{4+}$ cells of individuals.

Procedure for Adults: Twenty (20) $\mu 1$ of whole blood (K-EOTA as anticoagulant) was added to sample tube. Then, $20 \mu \mathrm{l}$ of $\mathrm{CD}^{4+} \mathrm{mAb} \mathrm{PE}$ was added; mixed gently and incubated for 15 minutes at room temperature and protected from light. About $800 \mu$ l of no-lyse buffer was added and mixed gently; and analyzed using the Portec Cyflow Counter Machine.

Procedure for children: About 20ul of whole blood (K-EDTA) as anticoagulant) was added to a sample tube. Then, $10 \mu \mathrm{l}$ of $\mathrm{CD}^{4+} \mathrm{mAb} \mathrm{PE}$ and $10 \mu \mathrm{l}$ of $\mathrm{CD} 45 \mathrm{mAb}$ were 
added and was protected from light. Four hundred (400) $\mu$ l of buffer 1 was added and mixed gently. Directly prior 10 the measurement $400 \mu$ l of buffer 2 was added end analysed using the Partec Cyflow Counter machine.

\subsection{Calculation of Results in $\mathrm{CD}^{4+}$ Sample}

During the staining procedure with the $\mathrm{CD}^{4+}$ easy count kit, the blood sample was diluted by a factor of 42 . The machine already takes this dilution factor into account and display directly the number the $\mathrm{CD}^{4+} \mu \mathrm{T}$-cell per $\mu$ l undiluted blood sample.

$$
\text { Dilution }=20 \mu \mathrm{l}+10 \mu \mathrm{l}+10 \mu \mathrm{l}+80 \mu \mathrm{l} / 20 \mu \mathrm{l}
$$

\subsection{Statistical Analysis}

Microsoft Excel and SPSS were used to analyze data. Frequency distribution table, percentages, prevalence of infection Attributed to intestinal protozoans in HIV/AIDS patients was estimated. Furthermore, Chi-square test was used to compare prevalence of infection between sexes, ages and location. The level of significance was set at $\mathrm{P} \leq 0.05$.

\section{Results}

Table 1 shows the age and gender specific prevalence of opportunistic intestinal protozoan among HIV in positive patients which reveals that the prevalence was higher among female positives $68(19.60 \%)$ than the male $50(16.50 \%)$. Chi-square analysis showed no statistically significant difference $(p>0.05)$ in infection among sexes. On the other hand, the occurrence of intestinal protozoan infection based on age group revealed that the age group between 10-15 years had the highest prevalence of 27 (48.21\%), followed by $26-30$ years age group $(28.13 \%)$. The least prevalence of 2 $(2.63 \%)$ was recorded among $41-45$ years in a decreasing order respectively. The Chi square analysis revealed that there is association between age and gender and the occurrence of Opportunistic Intestinal protozoan infection among HIV sero-positive $p \leq 0.05$.

Table 1. Age and Gender Specific Infections of Intestinal protozoan in HIV Subject in study area.

\begin{tabular}{|c|c|c|c|c|c|c|}
\hline Age (Years) & No. Exam & No. Inf (\%) & No. Exam & No. Inf (\%) & No. Exam & No. inf \\
\hline $10-15$ & 33 & $12(36.36)$ & 23 & $15(65.21)$ & 56 & $27(48.21)$ \\
\hline $16-20$ & 33 & $7(21.21)$ & 42 & $11(26.19)$ & 75 & $18(24.0)$ \\
\hline $21-25$ & 29 & $7(24.13)$ & 42 & $8(19.04)$ & 71 & $15(21.13)$ \\
\hline $26-30$ & 34 & $11(32.35)$ & 30 & $7(23.33)$ & 64 & $18(28.13)$ \\
\hline $31-35$ & 47 & $4(8.51)$ & 54 & $11(20.37)$ & 101 & $15(14.85)$ \\
\hline $36-40$ & 41 & $3(7.32)$ & 54 & $6(11.11)$ & 95 & $9(9.47)$ \\
\hline $41-45$ & 33 & $1(3.03)$ & 43 & $1(2.33)$ & 76 & $2(2.63)$ \\
\hline 51 above & 21 & $3(14.28)$ & 19 & $5(26.32)$ & 40 & $8(20.00)$ \\
\hline TOTAL & 303 & $50(16.50)$ & 347 & $68(19.60)$ & 650 & $118(18.15)$ \\
\hline
\end{tabular}

Table 2 shows the prevalence of opportunistic intestinal protozoan parasites in relation to $\mathrm{CD}^{4+} \mathrm{T}$-cell count of HIV and non-HIV infected patients in Jalingo. The result showed that $34.75 \%$ of the subjects had a $\mathrm{CD}^{4+}$ cell count of less than 200 cells $/ \mathrm{mm}^{3}$ while $55.93 \%$ of the HIV sero-positive subject had a $\mathrm{CD}^{4+}$ cell count between $200-500$ cells $/ \mathrm{mm}^{3}$ and $9.32 \%$ had a $\mathrm{CD}^{4+}$ count greater that 500 cells $/ \mathrm{mm}^{3}$. For the sero-negative subjects, $60.00 \%$ had a $\mathrm{CD}^{4+}$ count of greater than 500 cells $/ \mathrm{mm}^{3}$ while $13.33 \%$ had a $\mathrm{CD}^{4+}$ count less than 200 cells $/ \mathrm{mm}$. The Chi square analysis revealed that there is association $(p \leq 0.05)$ between the occurrence of opportunistic intestinal protozoan infection and $\mathrm{CD}^{4+} \mathrm{T}$-cell count among HIV and Non HIV infected patients.

Table 2. Prevalence of Opportunistic Intestinal Protozoan Infection in relation to CD ${ }^{4+}$ T-cell count among HIV and HIV infected subjects in Jalingo Metropolis.

\begin{tabular}{|c|c|c|c|c|}
\hline & \multicolumn{4}{|c|}{$\mathrm{CD}^{4}$ T-cell count $(\%)$} \\
\hline & No examined & $<200$ cells $/ \mathrm{mm}$ & $200-500$ cells $/ \mathrm{mm}^{3}$ & $\geq 500$ cells $/ \mathrm{mm}^{3}$ \\
\hline HIV sero-positive & 118 & $41(34.75)$ & $66(55.93)$ & $11(9.32)$ \\
\hline HIVsero-negative & 15 & $2(13.33)$ & $4(26.67)$ & $9(60.00)$ \\
\hline Total & 133 & 43 & 70 & 20 \\
\hline
\end{tabular}

The sex specific prevalence of intestinal opportunistic protozoan parasites in relation to $\mathrm{CD}^{4+} \mathrm{T}$-cell count among HIV sero-positive subjects as depicted in Table 3 revealed that large proportion of the female subjects $(58.54 \%)$ had $\mathrm{CD}^{4+}$ count lest than 200 cells $/ \mathrm{mm}^{3}$ ) compared to their male counterpart $(41.46 \%)$. The Chi-square analysisshowed no significant association $(p \leq 0.05)$ between the occurrence of opportunistic intestinal protozoan infections with gender and $\mathrm{CD}^{4+} \mathrm{T}$-cell count among HIV Sero-positive subjects.
Table 4 showed the occurrence of opportunistic protozoan infection and $\mathrm{CD}^{4+}$ T-cell count among HIV infected patients, majority of sero-positive HIV subjects with intestinal protozoan parasites had a $\mathrm{CD}^{4+}$ count of less than 200 cells $/ \mathrm{mm}^{3}$ at $68(57.63 \%)$ while $11(9.32 \%)$ had $\mathrm{CD}^{4+}$ count of above 500 cells $/ \mathrm{mm}^{3}$. Based on species, Cryptosporidium spp $29(24.58 \%)$ had the highest association with $\mathrm{CD}^{4+}$ count less than 200 cells $/ \mathrm{mm}^{3}$. Giardia lamblia had no significant association with $\mathrm{CD}^{4+}$ count level $<200$ cells $/ \mathrm{mm}^{3}$ to $>500$ 
cells $/ \mathrm{mm}^{3}$. However, Entamoeba histolytica had varying $\mathrm{CD}^{4+}$ count level of $19(16.10 \%)$ to 5 (4.24) out of the 30 tested positive subjects. Of the 40 tested positive subjects Entamoeba coli had varying $\mathrm{CD}^{4+}$ count levels of $20(16.95 \%)$ to 4 (3.39) with $<200$ cells $/ \mathrm{mm}^{3}$ to $<500$ cells $/ \mathrm{mm}^{3}$ respectively in decreasing order. There was a statistically significant association between $\mathrm{CD}^{4+}$ count in relation to Entamoeba histolytica. Cryptosporidium parvum and Entamoeba coli. Chi-square analysis showed that there is association $(p<0.05)$ between the occurrence of opportunistic protozoan infection and $\mathrm{CD}^{4+} \mathrm{T}$-cel count among HIV and non-HIV infected patients.

Table 3. Distribution of Opportunistic Intestinal Protozoan Infection in relation to $C D^{4+}$ T-cell count among HIV sero-positive subjects.

\begin{tabular}{llll}
\hline $\mathbf{C D}^{\mathbf{4 +}}\left(\mathbf{C e l l s} / \mathbf{m m}^{\mathbf{3}}\right)$ & Male (\%) & Female (\%) & Total (\%) \\
\hline$<200$ & $17(41.46)$ & $24(58.54)$ & $41(6.31)$ \\
$200-500$ & $29(43.94)$ & $37(56.06)$ & $66(10.15)$ \\
$>500$ & $5(45.45)$ & $6(54.54)$ & $11(1.06)$ \\
Total & $51(43.22)$ & $67(56.78)$ & $118(18.15)$ \\
\hline
\end{tabular}

Table 4. Association between parasites species and $C D^{4+}$ T-cell count of HIV sero-positive subjects in the study area.

\begin{tabular}{|c|c|c|c|c|}
\hline \multicolumn{5}{|l|}{$\mathrm{CD}^{4+} \mathrm{T}-\mathrm{Cell}$ count $(\%)$} \\
\hline & No. pos & $<200$ Cells $/ \mathrm{mm}^{3}$ & $200-500 \mathrm{ells} / \mathrm{mm}^{3}$ & $>500 \mathrm{Cells} / \mathrm{mm}^{3}$ \\
\hline Giardia lamblia & 2 & $0 .(0.00)$ & $2(1.69)$ & $0(0.00)$ \\
\hline Entamoeba histolytica & 30 & $19(16.10)$ & $6(5.08)$ & $5(4.24)$ \\
\hline Entamoeba coli & 40 & $20(16.95)$ & $16(13.56)$ & $4(3.39)$ \\
\hline Total & 118 & $68(57.63)$ & $39(33.05)$ & $11(9.32)$ \\
\hline
\end{tabular}

\section{Discussion}

It was observed that the prevalence of opportunistic Intestinal protozoan infection was lower among patients whose $\mathrm{CD}^{4+}$ count was higher than 200 cells/ $\mu \mathrm{l}$ while prevalence of infection increased when $\mathrm{CD}^{4+}$ count was low. This is because deficiency of immune system due to HIV/AIDS infection reduces the immune response to intestinal parasite infection. This supports the findings of Rossignol et al. [4] who observed similar pattern in the State place of his research while working among HIV/AIDS patients. The use of $\mathrm{CD}^{4+}$ t-lymphocytes to monitor HIV patients on ART has been shown to be highly indicative of their morbidity status. It has been established that a weakened immune system depicted by low $\mathrm{CD}^{4+}$ count result in high susceptibility of the individual to co-morbidities. This is why the World Health Organization recommended the use of $\mathrm{CD}^{4+}$ count to monitor opportunistic infections [5].

Intestinal protozoan infection in relation to $\mathrm{CD}^{4+}$ count between males and females showed that, female had higher $\mathrm{CD}^{4+}$ count than their male counterparts. This could be due to maternal age/gestational age and PCV at booking that did not influence the $\mathrm{CD}^{4+}$ cell count in HIV-infected pregnant women. Akinsegun et al. [6] reported such cases in his study.

Intestinal protozoan infections in HIV/AIDS subjects require a careful study in a developing world where poor nutrition is associated with poor hygiene and several tropical diseases. The parasite detected in this study for HIV/AIDS subjects include Cryptosporidium species (7.10\%), Entamoeba coli (6.15\%), Entamoeba histolytica (5\%) and Giardia lamblia (2\%). Cryptosporidium species was found to be significantly higher in HIV/AIDS subject than in the control samples. This could be transmitted to relatively low immune status of subject with HIV/AIDS. This is in agreement with the research carried out by Babatunde et al. [7] who reported intestinal parasitic infections are the major causes of morbidity and mortality in HIV positive patients according to the study of Assefa et al. [8] and Adamu and Petros [9]. A significant number of parasites-positive participants in this study had $\mathrm{CD}^{4+}$ count levels of 200-500 cells $/ \mu$ i.e. $200-500$ cells $/ \mathrm{mm}^{3}$ and below 200 cells $/ \mathrm{mm}^{3}$. It was found that, participants with Cryptosporidlum spp were significantly associated with $\mathrm{CD}^{4+}$ count below 200 cells $/ \mathrm{mm}^{3}$ this is because HIV/AIDS infection has been shown to predispose patients highly to intracellular opportunistic intestinal parasites such as Cryprosporidium. The association between opportunistic intestinal parasites have been explained by various researchers; this is in agreement, with the findings of Weber et al. [10]. The association of opportunistic parasites with $\mathrm{CD}^{4+}$ counts below 200 cells/ $\mu \mathrm{l}$ in this study was significant because of the depletion of the immune system due to HIV/AIDS. This was in line with studies done elsewhere which include, that done in Ethiopia, India and Brazil [8, 9, 11 , 12]. Another study done in Benin City, Nigeria by Akinbo et al. [13] also reported that Cryptosporidium infections were significantly associated $(\mathrm{p} \leq 0.05)$ with $\mathrm{CD}^{4+}$ count below 200 cells $/ \mu 1$.

The other pertinent finding was that in immunocompromised patients whose $\mathrm{CD}^{4+} \mathrm{T}$ cell count fell below 500 cells $/ \mathrm{mm}^{3}$; they were more likely be infected with intestinal parasites. This is in agreement with previous finding in Nigeria by Akinbo et al. [13], in Nepal by Tiwari et al. [14] and in Ethiopia by Teklay et al. [15].

\section{Conclusion}

This study report the prevalence of intestinal parasites among HIV/AIDS patients with special emphasis on the sero-positive status and $\mathrm{CD}^{4+}$ count levels of the infected subjects. The prevalence of intestinal parasites was highly significant among the study participants with $\mathrm{CD}^{4+}$ count $<200$ cells/ $\mu$ l. Cryptosporidium spp was significantly associated with HIV positive subjects who had $\mathrm{CD}^{4+}$ count of less than 200 cell $/ \mu 1$. Routine stool examination should be enforced and performed regularly during the follow-up of 
HIV/AIDS patients who attend HIV clinics for early diagnosis and treatment of the specific parasites in these patients. Since HIV/AIDS disease coexist with intestinal parasite infections as indicated in this study, it is imperative that the National AIDS Control Programme provides the necessary logistics required to diagnose specific opportunistic intestinal parasites. This should include PCR, Isoenzyme Analysis and Antigen detection which has proven to be a very effective means of diagnosing intestinal parasites. All diagnostic techniques for parasites detection especially opportunistic parasites should be made widely available at HIV clinics. It is recommended that clinicians caring for HIV/AIDS patients should request for routine stool examination for the specific diagnosis of opportunistic intestinal parasites, especially in patients at the symptomatic stage $\mathrm{CD}^{4+}$ T-cell count: $50-200$ cells/ $\mu \mathrm{l}$ ) of HIV disease.

\section{References}

[1] Gupta, K., Bala, M., Deb, M., Muralidhar, S. and Sharma Prevalence of intestinal parasitic infections in HIV-infected individuals and their relationship with immune status. Indian Journal of Medical Microbiology, 2013; 31: 161-165.

[2] National Agency for the Control of AIDS. Report on prevalence of HIV/AIDS in Nigeria-National Agency For The Control of HIV/AIDS, 2015; Pg 1129-1178.

[3] Sparks, H., Nair, G., Castellanos-Gonzalez, A., White, A. C. Jr. Treatment of Cryptosporidium: What We Know, Gaps, and the Way Forward. Curr Trop Med Rep 2015; 2: 181.

[4] Cheesbrough M. District laboratory practice in tropical countries. New York-Cambridge Press. Part 1, $2^{\text {nd }}$ Edition, 2012; 249-258.

[5] World Health Organization. Consolidated guidelines on the use of antiretroviral drugs for treating and preventing HIV infections. Recommendation for Public Health approach, 2016; 2. 236-287.

[6] Akinsegun, A., Olusola, D. A., Sarah, J. O., Olajumoke, O., Adewumi, A., Majeed, O. and Kingsley, A. Quality of sleep in an HIV population on antiretroviral therapy at an urban tertiary centre in Lagos, Nigeria. Neurology Research International, 2015; 18: 1014-1020.
[7] Obateru, O. A., Bojuwoye, B. J., Olokoba, A. B., Fadeyi, A. F., Olokoba, L. B. Prevalence of intestinal parasites in newly diagnosed HIV/AIDS patients in Ilorin, Nigeria. Alexandria Journal of Medicine, 2017; 53 (2): 111-116

[8] Bokore A, Korme B, Bayisa G. Determinants of anti-retroviral regimen changes among HIV/AIDS patients of east and west Wollega zone health institutions, Oromia region, west Ethiopia: a cross-sectional study. BMC Pharmacol Toxicol 2018; 19 (1): 28 .

[9] Gebretsadik D, Haileslasie H, Feleke DG. Intestinal parasitosis among HIV/AIDS patients who are on anti-retroviral therapy in Kombolcha, North Central, Ethiopia: a cross-sectional study. BMC Res Notes. 2018; 11 (1): 613. doi: 10.1186/s13104-018-3726-6.

[10] Wilcox, C. M. Evaluation of the HIV-infected patient with diarrhea. Update, 2018.

[11] Alemu G, Alelign D, Abossie A. Prevalence of Opportunistic Intestinal Parasites and Associated Factors among HIV Patients while Receiving ART at Arba Minch Hospital in Southern Ethiopia: A Cross-sectional Study. Ethiop J Health Sci. 2018; 28 (2): 147-156. doi: 10.4314/ejhs.v28i2.6

[12] Barcelos Natane Barbosa, Silva Lorena de Freitas e, Dias Regyane Ferreira Guimarães, Menezes Filho Hélio Ranes de, Rodrigues Rosângela Maria. Opportunistic and non-opportunistic intestinal parasites in HIV/ AIDS patients in relation to their clinical and epidemiological status in a specialized medical service in Goiás, Brazil. Rev. Inst. Med. trop. S. Paulo [Internet]. 2018 [cited 2020 Aug 18]; 60: e13. Available from: http://www.scielo.br/scielo.php?script=sci arttext\&pid=S0036 $-46652018005000206 \& \operatorname{lng}=$ en. Epub Mar 08, 2018. https://doi.org/10.1590/s1678-9946201860013.

[13] Akinbo F O, Anate P J, Akinbo D B, Omoregie R, Okoosi S, Abdulsalami A, Isah B. Risk factors of intestinal parasitic infections among human immunodeficiency virus-infected patients on highly active antiretroviral therapy. Port Harcourt Med J, 2017; 11: 15-20.

[14] Tiwari, B. R., Ghimire P., Malla, S., Sharma, B. and Karki, S. Intestinal parasitic infection among the HIV-infected patients in Nepal. Journal of Infection in Developing Countries, 2013; 7 (07): 550-5555.

[15] Teklay, G., Haftom, K., Abebaw, A. G. Intestinal parasites among HIV/AIDS patients attending University of Gondar Hospital, northwest Ethiopia. Ethiop. J. Health Dev. 2019; 33 (2): 64-72. 